\title{
APPLIED METHODS OF MEASURING WHEN SELECTING MECHANICAL AND TRIBOLOGICAL PROPERTIES OF MATERIALS
}

\author{
D. Ješić \\ Tribotehnik, Titov trg 6/4, 51000 Rijeka, Croatia
}

\begin{abstract}
This paper presents a part of the results of experimental research of tribological and mechanical properties of two types of isothermally upgraded nodular castings and one type of alloyed steel in contact with carbon steel and grey pig-iron casting. The research was performed on a device with a rotating disk and a stationary pin. The obtained results of wear are presented as diagrams.
\end{abstract}

Keywords: wear, material and contact.

\section{INTRODUCTION}

Tribological properties of materials are determined by either measuring of friction force in contact area or by measuring wear of one element of tribo-mechanical system. The amount of friction force as well as the wear of one or both elements of tribomechanical system after a certain period of contact depends on numerous factors which define the conditions under which the contact is made (external load, velocity of gliding, type of lubricant et cetera) [1].

Tribological properties of materials after a certain period of contact are relative and depend both on methods by which they were determined and on conditions under which the contact between tribo-mechanical system elements is made. Comparison shows whether tribological properties are determined by measuring the friction force, i.e. friction coefficient or by measuring the extent of wear of one of the tribological system elements. Having said that, the conditions for contact creation can significantly affect the ratio of tribological properties of two materials.

Methods for laboratory-conditioned measurement of tribological properties are as a rule based on the application of "Pin on Disk" tribometer where all three basic contact geometry forms may be exercised (dot, line, surface).

Modern equipment and devices embedded in tribometers, as well as related instrumentation, make possible performing precise and reliable measurement of normal force or friction force, i.e. friction coefficient [1].

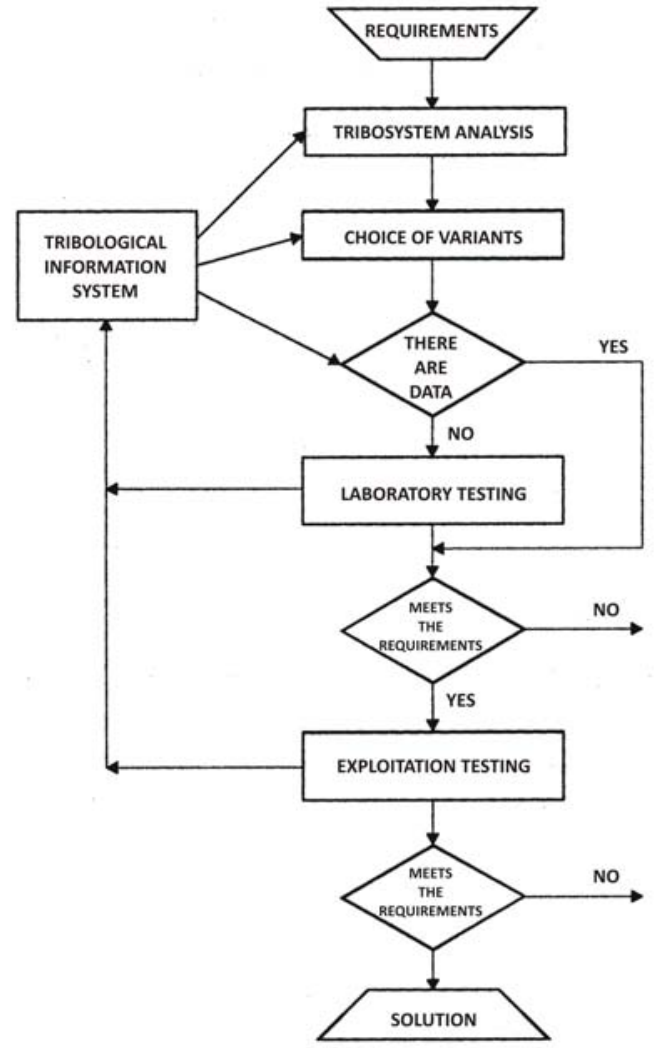

Figure 1. Procedure of selection of tribosystem element materials

Wear of either a pin or a disk after a certain period of contact is measured by using numerous methods based on measuring of their dimensions (pin length or disk cross-section) or grooves left by wear process in contact surfaces of element in contact. Reliability and accuracy of these measurements are relatively low if the contact period is not long. With emergence of more extensive wear of elements of tribo-mechanical systems of this type (pin or disk) 
that facilitates greater measurement reliability it is necessary to change either a disk or a pin when turning to other conditions of contact (different gliding velocity). Change of either a pin or a disk during the implementation of some research programme can lead to slight reoccurrence of measuring results and to increased number of experiments aimed at assuring sufficient reliability of research results.

This paper presents a part of research programme where two disks have been used: one made of grey pig-iron casting GPIC 250 and the other made of steel S 1530. Pins are made of nodular castings
$\mathrm{NC} 420$ and $\mathrm{NC} 600$, and the third pin is made of steel S 3840; the latter will be addressed in this paper [2].

\section{PROGRAMME AND CONDITIONS FOR EXPERIMENTAL RESEARCH}

Experimental research has been implemented on "pin on disk" tribometer with effected linear contact between frontal pin surface and perimeter disk surface [4].

Table 1. Chemical composition of nodular castings NC 420 and NC 600

\begin{tabular}{|c|c|c|c|c|c|c|c|}
\hline \multirow{2}{*}{$\begin{array}{c}\text { Nodular } \\
\text { casting }\end{array}$} & \multicolumn{7}{|c|}{ Chemical composition in \% } \\
\cline { 2 - 9 } & $\mathrm{C}$ & $\mathrm{Si}$ & $\mathrm{Mn}$ & $\mathrm{Mg}$ & $\mathrm{P}$ & $\mathrm{S}$ & $\mathrm{Cu}$ \\
\hline $\mathrm{NC} 420$ & 3.62 & 2.52 & & 0.28 & 0.020 & 0.006 & \\
\hline NC 600 & 3.67 & 3.20 & 0.59 & & 0.025 & 0.040 & 1.38 \\
\hline
\end{tabular}

Table 2. Measured properties of nodular casting pins

\begin{tabular}{|c|c|c|c|c|}
\hline \multirow{2}{*}{$\begin{array}{l}\text { Nodular } \\
\text { casting }\end{array}$} & \multicolumn{2}{|c|}{ Thermal processing conditions } & \multirow{2}{*}{$\begin{array}{l}\text { Hardness } \\
\text { in } \mathrm{HV}_{5}\end{array}$} & \multirow{2}{*}{ Structure } \\
\hline & $\begin{array}{l}\mathrm{T}_{\mathrm{a}} \mathrm{u}{ }^{\circ} \mathrm{C} / \mathrm{t} \text { u min } \\
\mathrm{T}_{\mathrm{a}} \text { in }{ }^{\circ} \mathrm{C} / \mathrm{t} \text { in min }\end{array}$ & $\begin{array}{l}\mathrm{T}_{\mathrm{p}} \mathrm{u}{ }^{\circ} \mathrm{C} / \mathrm{t} \text { u min } \\
\mathrm{T}_{\mathrm{p}} \text { in }{ }^{\circ} \mathrm{C} / \mathrm{t} \text { in min }\end{array}$ & & \\
\hline NC 420 & $900 / 60$ & $390 / 90,390 / 60,390 / 30$ & 295 & Ferric-pearlitic \\
\hline NC 600 & $900 / 60$ & $390 / 90,390 / 60,390 / 30$ & 320 & mainly pearlitic \\
\hline
\end{tabular}

Table 3. Comparison of nodular castings properties

\begin{tabular}{|ll|r|r|}
\hline \multicolumn{2}{|c|}{ Mechanical properties } & NC 420 at outset & NC 600 at outset \\
\hline Tensile strength & $\mathrm{R}_{\mathrm{m}}\left[\mathrm{N} / \mathrm{mm}^{2}\right]$ & 421 & 596 \\
\hline Liquid limit & $\mathrm{R}_{\mathrm{p} 0.2}\left[\mathrm{~N} / \mathrm{mm}^{2}\right]$ & 286 & 378 \\
\hline Post-tearing elongation & $\mathrm{A}_{5}[\%]$ & 22 & 8.9 \\
\hline Post-tearing narrowing & $\mathrm{Z}[\%]$ & 19 & 270 \\
\hline Hardness & $\mathrm{HB}$ & 150 & 12.6 \\
\hline Impact energy & $\mathrm{K}[\mathrm{J}]$ & 15 & \\
\hline
\end{tabular}

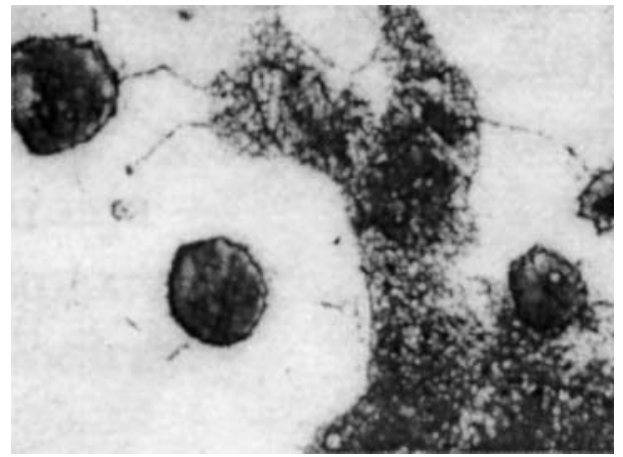

Figure 2a. Structure of NC 420 batch 5815-13, magnification 500x, eroded, ferric-pearlitic bases

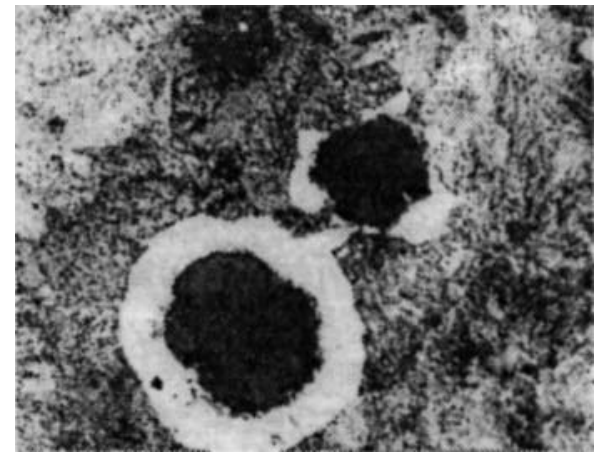

Figure 2b. NC 600, batch 5766-13, magnification 500x, eroded, mainly pearlitic bases 


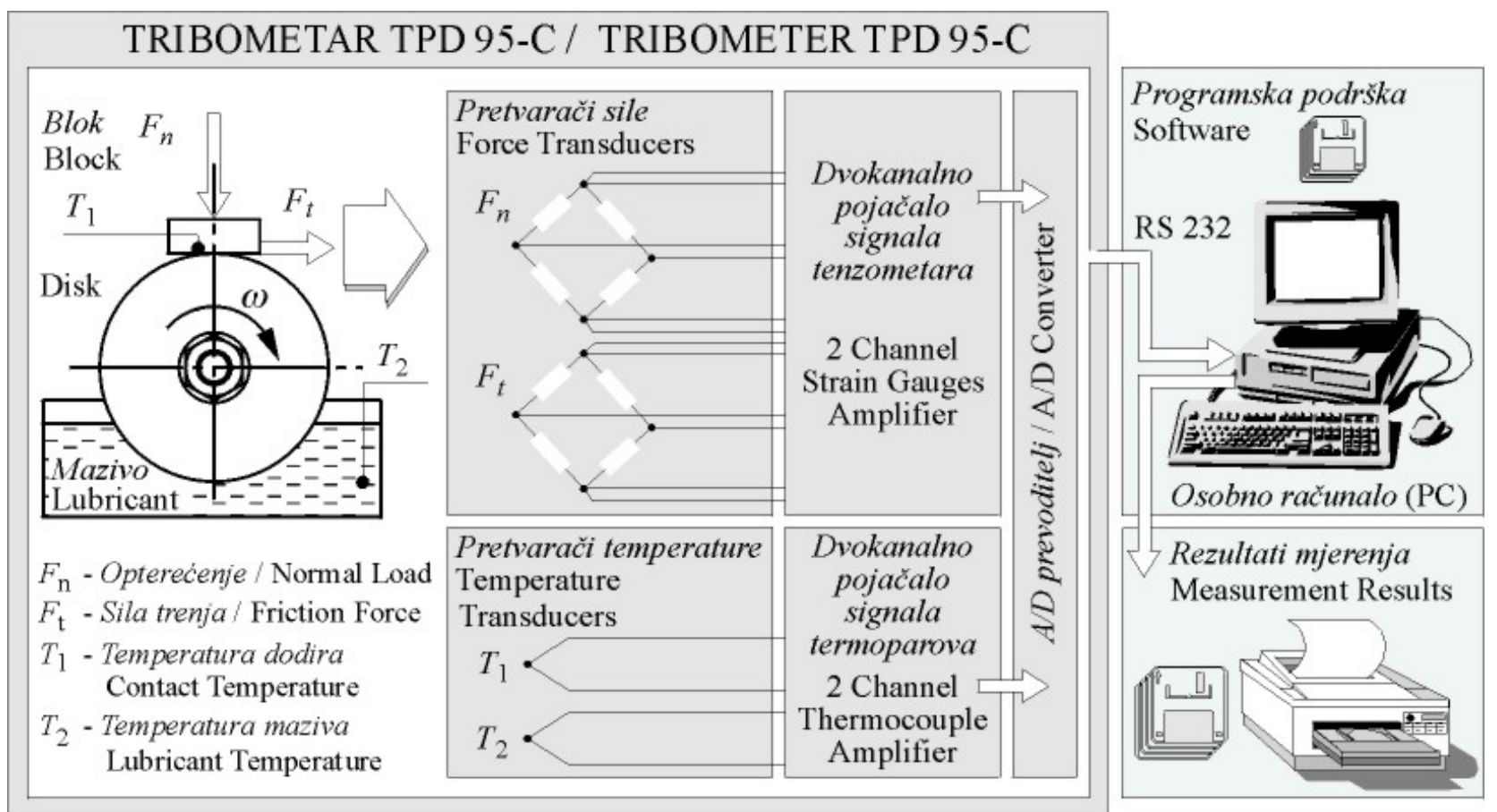

Figure 3. TPD 95-C “Pin on Disk” Tribometer with related instrumentation

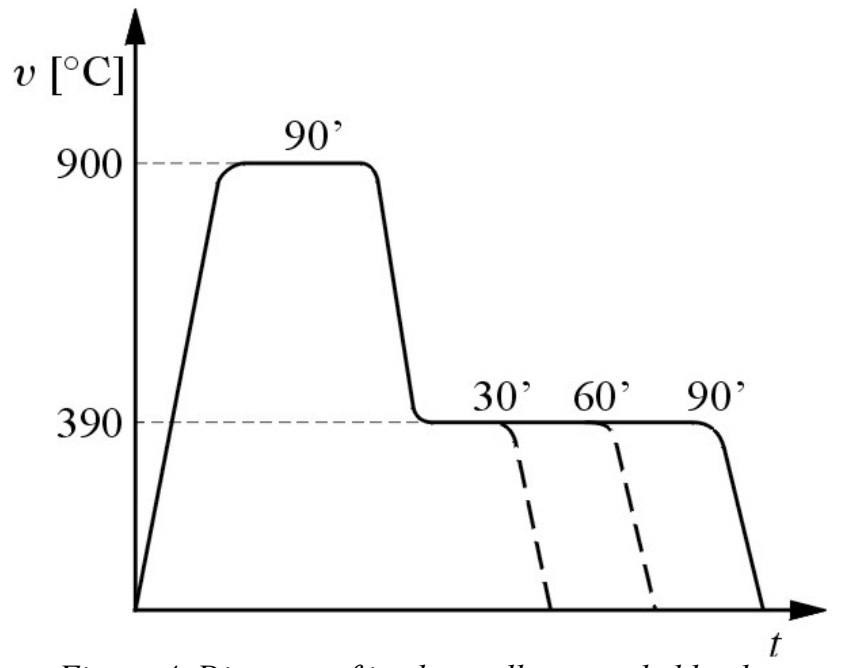

Figure 4. Diagram of isothermally upgraded beaker

\subsection{Isothermal upgrade of nodular castings} nc 420 and 600

An object undergoes isothermal upgrade so that it is rapidly cooled from austenisation temperature to isotherm temperature which is higher than the temperature at which martensite begins to form. It is kept at temperature $\mathrm{T}_{i}$ for a period of time until desired transformation is effected, and then air-cooled. The aim is to avoid transformation of austentite into martensite because it causes tension and cracks. Ke- eping at $\mathrm{T}_{i}$ temperature produces the so-called intermediate structure bianite. It provides an object with extremely superior mechanical properties when processed.

Isothermal upgrade was done in Thermal Processing Laboratory within the Faculty of Engineering and Shipbuilding in Zagreb

\subsection{Testing programme}

The testing programme envisages usage of two disks, one made of grey pig-iron casting GPIC 250 and the other of steel S 1530. Three pins, of which two are made of nodular casting NC 420 and NC 600 and one made of steel S 3840, partially mentioned in this paper.

The testing programme foresees running of 10 experimental tests in duration of 60 minutes of effective contact along with marginal lubrication.

Table 4.Testing conditions

\begin{tabular}{|l|c|c|}
\hline Normal load $\quad[\mathrm{N}]$ & 200 & 200 \\
\hline Temperature & environmental & environmental \\
\hline Gliding velocity $[\mathrm{m} / \mathrm{s}]$ & 2 & 2 \\
\hline Type of lubrication & marginal & marginal \\
\hline Contact duration [min] & 60 & 60 \\
\hline
\end{tabular}


Table 5.Elements of tribo-mechanical system

\begin{tabular}{|l|c|c|}
\hline Contact geometry & line & line \\
\hline Pin material & NC 420,51 HRC & NC 600, 42 HRC \\
\hline \multirow{2}{*}{ Pin area } & $\begin{array}{c}R_{\mathrm{a}}=0,23 \mu \mathrm{m} \\
R_{\max }=1,7 \mu \mathrm{m}\end{array}$ & $\begin{array}{c}R_{\mathrm{a}}=0,25 \mu \mathrm{m} \\
R_{\max }=2,6 \mu \mathrm{m}\end{array}$ \\
\hline Disk material & $\mathbf{S ~} \mathbf{1 5 3 1}, \mathbf{5 2 H R C}$ & GPIC 250, 46 HRC \\
\hline \multirow{2}{*}{ Disk area } & $R_{\mathrm{a}}=0,60 \mu \mathrm{m}$ & $R_{\mathrm{a}}=0,50 \mu \mathrm{m}$ \\
$R_{\max }=6,2 \mu \mathrm{m}$ & $R_{\max }=4,2 \mu \mathrm{m}$ \\
\hline Lubricant & HVL-22 Modriča & HVL-22 Modriča \\
\hline
\end{tabular}

Table 6.Testing results

\begin{tabular}{|c|c|c|}
\hline Friction force $\quad[\mathrm{N}]$ & 20,8 & 20,8 \\
\hline Friction coefficient & 0,104 & 0,096 \\
\hline $\begin{array}{ll}b_{\text {pin (sr) }} & {[\mathrm{mm}]} \\
b_{\text {pin(av) }} & \\
\end{array}$ & 0,84 & 0,625 \\
\hline $\begin{array}{ll}\delta_{\text {pin(sr) }} & {[\mathrm{mm}]} \\
\delta_{\text {pin(av) }} & \\
\end{array}$ & 0,0013 & 0,00072 \\
\hline Disk area & $\begin{array}{l}R_{\mathrm{a}}=0,54 \mu \mathrm{m} \\
R_{\max }=6,0 \mu \mathrm{m}\end{array}$ & $\begin{array}{l}R_{\mathrm{a}}=0,43 \mu \mathrm{m} \\
R_{\max }=3,8 \mu \mathrm{m}\end{array}$ \\
\hline
\end{tabular}

Geometrija dodira $i$

istrošena površina pina

Contact geometry and

pin's surface wear

$b_{\mathrm{sr}}=b_{\mathrm{av}}=0,84 \mathrm{~mm}$

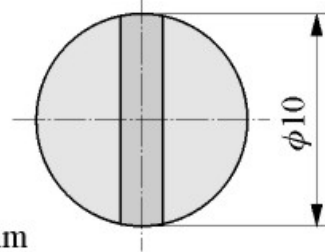

$$
\delta_{\text {pin }}=r_{\text {disk }}-\sqrt{r_{\text {disk }}^{2}-\left(\frac{b_{(\mathrm{sr})}}{2}\right)^{2}}
$$

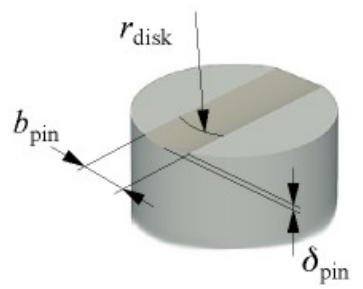

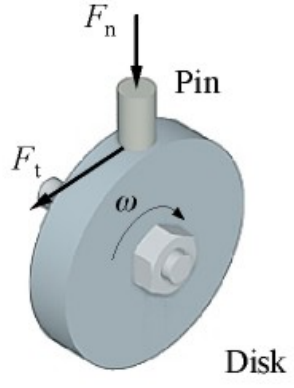

Figure 5.Contact geometry and worn pin surface which can be generalised and can relate to all tested materials

\section{RESEARCH RESULTS}

The intensity of wear of one element of tribomechanical system of any particular type, i.e. of selected parameter of wear in relation to contact duration between its elements is presented. Most often, the change of dimension of one element in contact is used as a wear parameter; in our case parameters of topography of pin and disk before and after the achievement the contact groove of the pin wear are important [3].
- Every point shown in friction coefficient diagrams represents the mean value of 750 points measured in 5-second interval.

- No oil film destruction has occurred during 60 minutes of constant contact test [5].

- The given values of width and depth of pin wear groove are obtained by measuring with a microscope and by calculation method, in line with the expression given in figure 4.
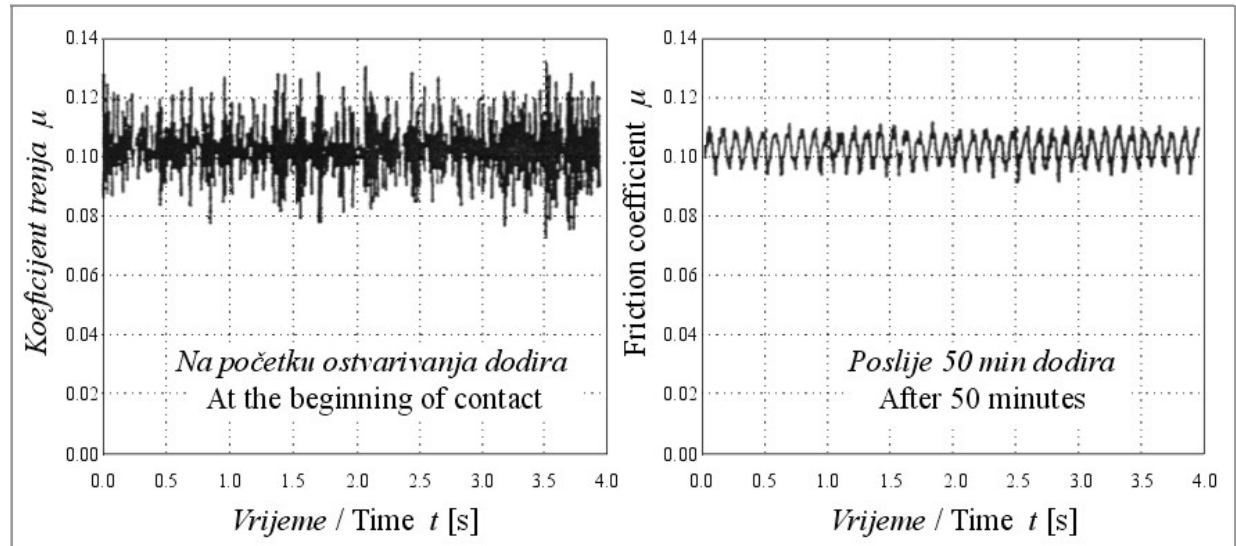

Figure 6. Shape of friction coefficient signal at the beginning and at the end of contact between pin NC 420 and disk $S$ 1531 


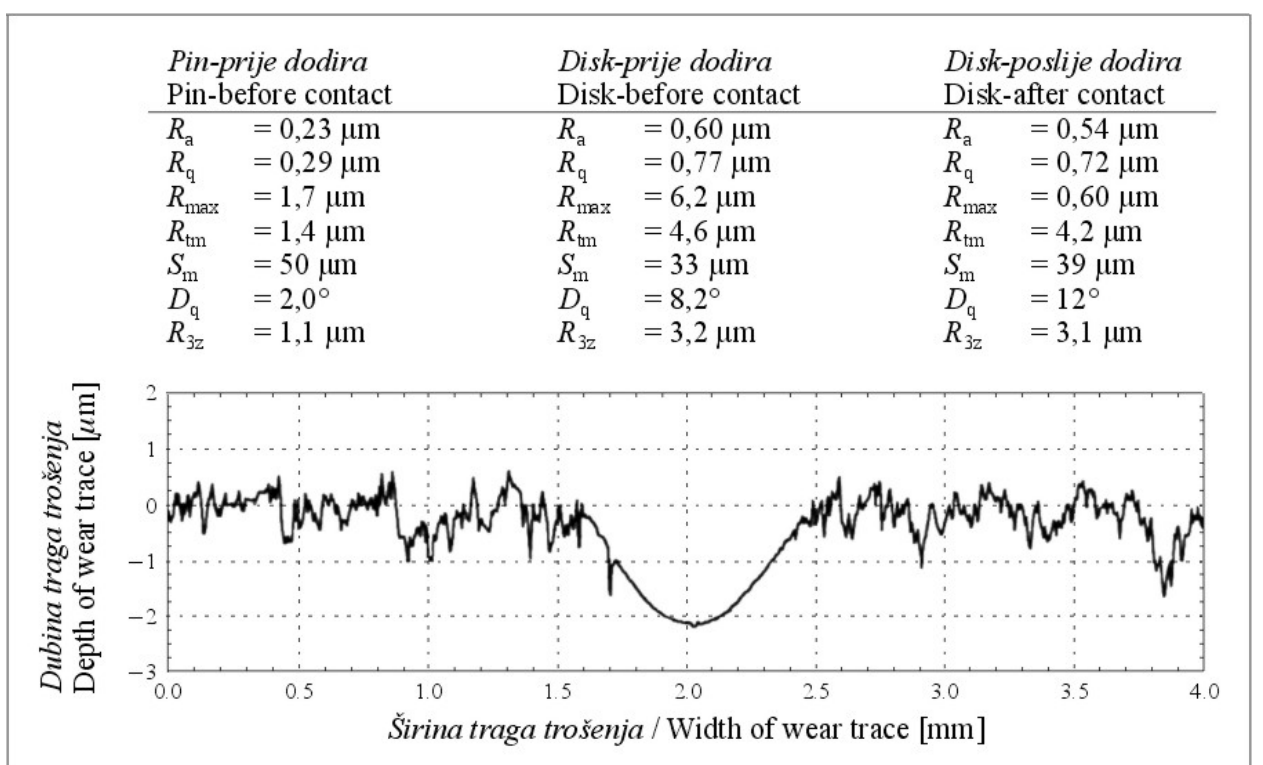

Figure 7. Pin and disk surface topography parameters before and after the beginning of the wear of pin NC 420 and disk $S 1531$

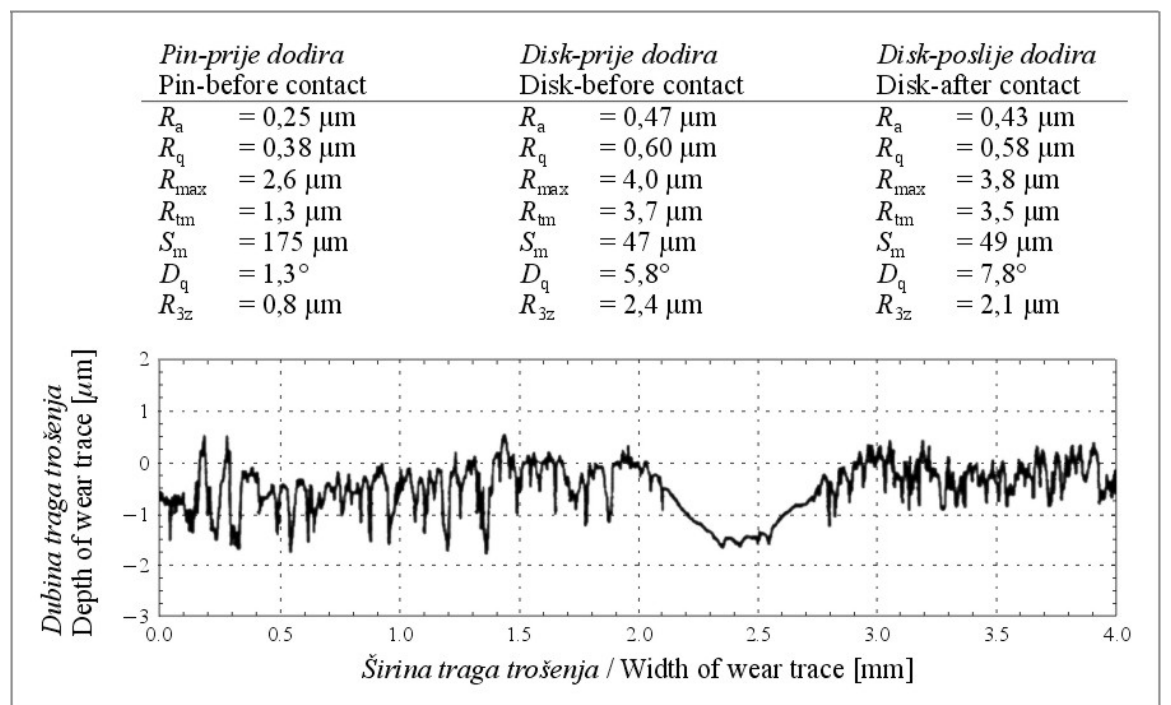

Figure 8. Pin and disk surface topography parameters before and after beginning of wear of pin NC 600 and disk $S 1531$

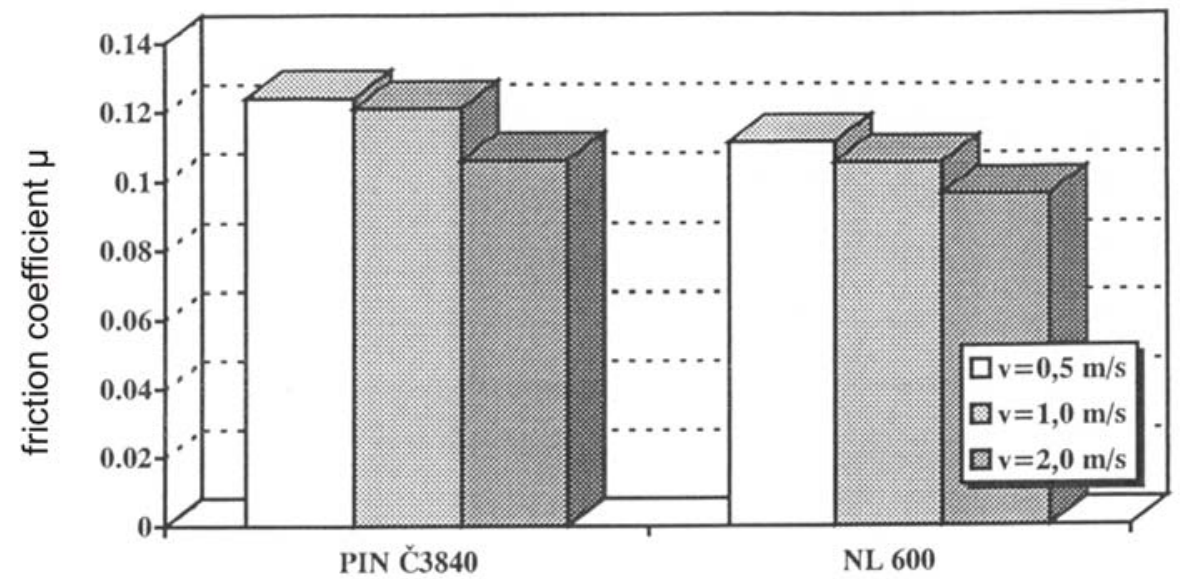

Figure 9. Friction coefficient depending on the materials of elements in contact at gliding velocity of $v=2 \mathrm{~ms}^{-1}$ and lubrication with HVL-22 measured after 30 minutes of contact 


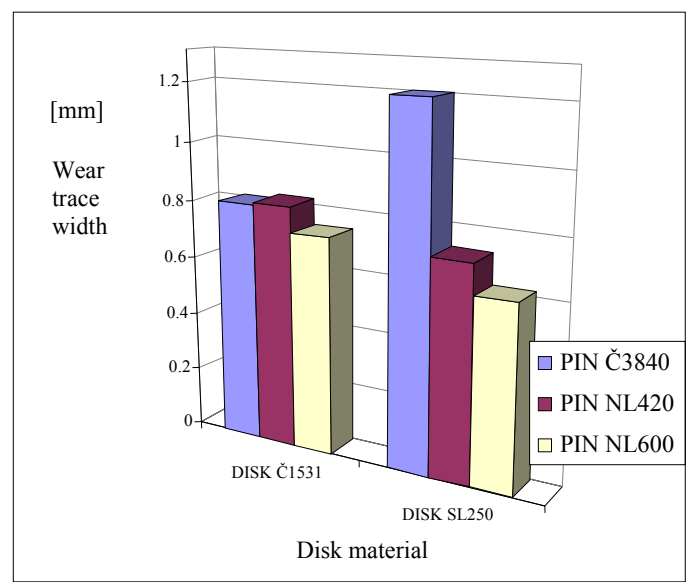

Figure 10. Wear groove width depending on the materials of elements in contact at gliding velocity of $v=2 \mathrm{~ms}^{-1}$ and lubrication with HVL-22 measured after 30 minutes of contact

\section{CONCLUSION}

Based on conducted experimental research, a conclusion can be drawn that the application of isothermal upgrade of both types of nodular casting can enhance their tribological properties measured through resistance to wear [6]. The greatest enhancement of resistance to wear has been achieved by isothermal upgrade of nodular casting $\mathrm{NC} 600$ by keeping it at temperature $T_{\mathrm{p}}$ during 60 minutes.

- Friction forces, i.e. friction coefficients are smaller with the contact between nodular casting (pins) and steel and casting (disks) compared to the friction force and friction coefficient that occur with the contact between steel on one side and steel and grey pig-iron casting on the other side.

- Smaller friction forces and friction coefficients have been achieved when using pin made of $\mathrm{NC}$ 600.

- The smallest wear groove has been achieved on pins made of nodular castings NC 420 and NC 600.

- It is very interesting to observe in Figure 7 the width of wear groove after certain duration of contact; the biggest wear groove during the contact time is visible in the middle of the wear curve.

- In relation to wear properties nodular castings have a significant advantage over steel.

- Nodular castings have a small but still considerable advantage over steel also with regard to their antifriction properties.

Generally speaking, from energetic and economic aspects, nodular castings have better tribological properties than steel tested under applied conditions. For concrete applications, however, it is necessary to test every material individually under concrete working conditions. It is also necessary to apply due caution to and have good knowledge of tribo-mechanical system, its complexity, significan- ce and reliability of individual part as well as which working conditions and the strain it is exposed to.

\section{LIST OF MARKS}

Tensile strength

Liquid limit

Post-tearing elongation

Post-tearing narrowing

Hardness

Impact energy

Upgrade temperature

Average profile deviation

Largest profile bottom depth

Average pin groove width

Disk radius

Pin groove depth

$\begin{array}{lc}R_{\mathrm{m}} & {\left[\mathrm{N} / \mathrm{mm}^{2}\right]} \\ R_{\mathrm{p} 0.2} & {\left[\mathrm{~N} / \mathrm{mm}^{2}\right]} \\ \mathrm{A}_{5} & {[\%]} \\ \mathrm{Z} & {[\%]} \\ \mathrm{HB} & \\ K & {[\mathrm{~J}]} \\ T_{\mathrm{p}}, T_{\mathrm{i}} & {[\mathrm{K}]} \\ R_{\mathrm{a}} & {[\mu \mathrm{m}]} \\ R_{\text {max }} & {[\mu \mathrm{m}]} \\ b_{\text {sr }} & {[\mathrm{mm}]} \\ r_{\text {disk }} & {[\mathrm{mm}]} \\ \delta_{\text {pin }} & {[\mathrm{mm}]}\end{array}$

Table 7. Comparative table of materials $H R N-D I N$

\begin{tabular}{|l|l|}
\hline HRN & DIN \\
\hline S 1531 & Ck45 \\
\hline S 3840 & 90MnV8 \\
\hline GPIC 250 & GG-25 \\
\hline NC 420 & GGG-40 \\
\hline NC 600 & GGG-60 \\
\hline
\end{tabular}

\section{REFERENCES}

[1] B. Ivković, A. Rac, Tribologija, Jugoslovensko društvo za tribologiju, Kragujevac 1995, 49-76.

[2] S. Tanasijević, Tribološki ispravno konstruisanje, Mašinski fakultet u Kragujevcu, Kragujevac 2004, 27-42. 
[3] D. Ješić, Merna tehnika, Mašinski fakultet Banja Luka 2004.

[4] D. Ješić, Tribological Properties of Nodular Cast Iron, Journal of the Balkan Tribological Association, Sofia 2000.

[5] B. Sovilj, I. Sovilj-Nikolić, D. Ješić, Measurement methodology of characteristics and election of materials of elements of tribomechanical systems, Metalurgija 50 (2011) 2, 107-111.
[6] B. Sovilj, D. Ješić, I. Sovilj-Nikić, Identifikacija $i$ metode merenja triboloških karakteristika materijala, Cont. Agr. Engng. 36, 3 (2010) 295-305.

$\operatorname{son}$

\section{ПРИМИЈЕЊЕНЕ МЕТОДЕ МЈЕРЕЊА ПРИ ИЗБОРУ МЕХАНИЧКИХ И ТРИБОЛОШКИХ КАРАКТЕРИСТИКА МАТЕРИЈАЛА}

Сажетак: Рад представља приказ дијела резултата експерименталних истраживања триболошких и механичких карактеристика двије врсте изотермички побољшаних нодуларних лијевова и једне врсте легираног челика при остваривању додира с угљичним челиком и сивим лијевом. Истраживања су проведена на уређају са ротирајућим диском и мирујућим пином. Добијени резултати трошења приказани су у дијаграмском облику.

Кључне ријечи: трошење, материјал и додир. 